\title{
Pengaruh Pemberian Tepung Daun Pepaya (Carica papaya) dalam Ransum terhadap Performans Produksi Telur Puyuh (Coturnix coturnix japonica)
}

\author{
Rina Yunita, Warnoto, Tatik Suteky \\ Jurusan Peternakan, Fakultas Pertanian, Universitas Bengkulu \\ Jalan W.R. Supratman Kandang Limun Bengkulu 38371 \\ Email: rinayuni84@yahoo.co.id
}

\begin{abstract}
The purpose of this research is to evaluate the effect of papaya leaf meal (Carica papaya) in the diet on production performance of quail (Coturnix coturnix japonica). Data were analyzed using of Completely Randomized Design consisted of four treatment including papaya leaf meal of $0 \%, 2 \%, 4 \%$, and $6 \%$ and used 80 quail aged 36 weeks. The result indicated that the use of papaya leaf meal in ration up to $6 \%$ significantly $(\mathrm{P}<0,01)$ on feed consumption and did not significantly affect $(\mathrm{P}>0,05)$ on egg production, egg weight, and feed conversion. The result showed that the consumption and feed conversion was significantly different $(\mathrm{P}<0,01)$ and egg production and egg weigh were not significantly $(\mathrm{P}>0,05)$. The conclution diet with $6 \%$ papaya leaves meal in diet can reduce feed consumption without reduce performance.
\end{abstract}

Key words: Quail, papaya leaf meal, production performance

\begin{abstract}
ABSTRAK
Penelitian ini bertujuan untuk mengevaluasi pengaruh tepung daun pepaya (Carica papaya) dalam ransum terhadap performans produksi telur puyuh (Coturnix coturnix japonica). Data dianalisis menggunakan rancangan acak lengkap, yang terdiri dari empat perlakuan yaitu $0,2 \%, 4 \%$, dan $6 \%$ penambahan tepung daun pepaya dengan menggunakan puyuh umur 36 minggu sebanyak 80 ekor. Hasil penelitian menunjukkan bahwa penggunaan tepung daun pepaya dalam ransum sampai taraf $6 \%$ berpengaruh nyata $(p<0,01)$ terhadap konsumsi dan konversi ransum namun tidak berpengaruh nyata $(p>0,05)$ terhadap produksi telur dan berat telur. Dari penelitian ini dapat disimpulkanbahwa pemberian tepung daun pepaya dalam ransum puyuh petelur sampai taraf 6\% dapat menurunkan konsumsi dan konversi ransum tanpa menurunkan produksi telur dan berat telur puyuh.
\end{abstract}

Kata kunci: puyuh, tepung daun pepaya, performans produksi

\section{PENDAHULUAN}

Puyuh merupakan salah satu ternak unggas yang dapat memproduksi telur lebih dari 300 butir per ekor selama setahun dengan puncak produksi terjadi pada umur 4-5 bulan. Pada umur 9 bulan, produksi telur puyuh turun menjadi $70 \%$. Salah satu faktor terpenting dalam keberhasilan beternak puyuh adalah pakan (nutrisi). Selain dapat mempengaruhi produksi telur, pakan juga merupakan komponen terpenting dalam biaya produksi karena $60-80 \%$ dari biaya yang dikeluarkan digunakan sebagai biaya pakan.

Telur puyuh merupakan salah satu hasil peternakan yang memiliki nilai gizi yang tinggi dan disukai oleh konsumen. Tingginya permintaan konsumen terhadap ketersediaan telur puyuh perlu mendapat perhatian khusus. Salah satu upaya untuk memenuhi permintaan konsumen akan 
telur puyuh dan peningkatan produktivitasnya, maka perlu dicari alternatif untuk dapat meningkatkan produktivitas telur puyuh tanpa tambahan biaya produksi.Daun pepaya merupakan salah satu alternatif yang dapat digunakan untuk memperbaiki produksi maupun kualitas telur.

Daun pepaya mengandung beberapa senyawa yang dapat mempermudah kerja usus dan berguna untuk proses pencernaan (Kamaruddin dan Salim, 2003). Di dalam daun pepaya juga banyak terkandung enzim papain yang memiliki kemampuan untuk membentuk protein baru yaitu plastein dan enzim proteolitik yang dapat meningkatkan efisiensi proses pencernaan sehingga dapat

Hasil analisis Laboratorium Nutrisi Ternak Ruminansia dan Kimia Makanan Ternak Fakultas Peternakan Universitas Padjajaran (2007) menunjukkan bahwa daun pepaya mengandung protein kasar sebesar 20,88\%, kalsium $0,99 \%$, fosphor 0,47\%, dan gross energy 2912 kkal/kg. Selain itu, daun pepaya juga mengandung $\beta$ karoten yang dapat berfungsi sebagai pro vitamin A sebesar 18250 dan dapat digunakan sebagai sumber xantophyl alami (Anonimous, 1981). Sutama (2008) menemukan dalam 100 gram daun pepaya mengandung niasin 2,1 mg, vitamin C 140 mg, dan vitamin E 136 mg.
Menurut Ardina (2007) pada daun pepaya terkandung enzim papain yang berfungsi sebagai antimikrobial dan alkaloid yang berfungsi sebagai antibakteri. Enzim papain juga memiliki sifat sebagai antimikrobial yang dapat menghambat kinerja beberapa mikroorganisme. Komponen aktif B karoten (pro-vitamin A) pada daun pepaya dapat sebagai antioksidan (Sutama, 2008).

Pengaruh pemberian tepung daun pepaaya pada unggas telah diteliti oleh beberapa peneliti. Machasin (2007) menemukanbahwapenambahantepungdaun pepaya hingga taraf $18 \%$ persen dalam ransum basal ayam buras superdapatmengurangibiayapakan.

Penelitian Widjastuti (2009) terhadap ayam Sentul umur 36 minggu dengan pemberian tepung daun pepaya sampai batas $10 \%$ tidak berpengaruh negatif terhadap produksi telur. Sutama (2008) juga menemukan bahwa penambahan tepung daun pepaya sampai taraf 3\% tidak berpengaruh nyata terhadap produksi telur ayam Hysex Brown umur 19 minggu.Sedangkan penambahan sampai $2 \%$ daun pepaya dalam ransum tidak berpengaruh negatif terhadap konsumsi ransum dan produksi telur ayam buras (Paramita dkk., 2001). Penambahan daun pepaya sebanyak $6 \%$ dalam ransum komersial memberikan pengaruh terhadap konsumsi ransum, berat badan dan 
peningkatan konversi ransum pada ayam petelur jantan (Bota, 2007).

Hasil-hasil penelitian tersebut menunjukkan bahwa jenis unggas yang berbeda akan memberikan respon yang berbeda terhadap pemberian tepung daun pepaya. Sejauh ini belum ada informasi ilmiah pengaruh pemberian tepung daun pepaya terhadap performans produksi telur puyuh.

Penelitian ini bertujuan untuk mengevaluasi pengaruh pemberian tepung daun pepaya (Carica papaya) dalam pakanterhadap performans produksi telur puyuh.

\section{MATERI DAN METODE}

\section{Waktu dan Tempat}

Penelitian ini dilaksanakan selama 2 bulan, dimulai pada tanggal 26 April 2013 sampai 20 Juni 2013 di Commercial Zone of Animal Laboratory(CZAL) Jurusan Peternakan Fakultas Pertanian Universitas Bengkulu.

\section{Bahan dan Alat}

Bahan yang digunakan pada penelitian ini adalah puyuh Coturnix coturnix berumur 9 bulan, tepung daun pepaya, jagung giling, dedak halus, konsentrat komersial, mineral, dan top mix.

Alat yang digunakan pada penelitian ini adalah timbangan duduk kapasitas 10 $\mathrm{Kg}$ dengan ketelitian 50 gram, timbangan Ohaus kapasitas 500 g, tempat ransum, tempat minum, ember, sekop, terpal, seng, alat tulis dan lain-lain yang dianggap perlu.

\section{Tahapan Penelitian}

Pembuatan tepung daun pepaya menggunakan daun pepaya tua, pembuatan tepung dilakukan dengan cara menyiapkan daun pepaya tua kemudian dikering anginkan selama 4-5 hari. Kemudian daun pepaya yang telah dikering anginkan dijemur terlebih dahulu selama 2-3 jam dibawah matahari. Lalu daun pepaya yang telah kering digiling menggunakan mesin penggiling agar didapat hasil yaitu tepung daun pepaya. Komposisi nutrisi bahan penyusun ransum selengkapnya ditampilkan pada Tabel 1. 
Tabel 1. Komposisi nutrisi bahan penyusun ransum

\begin{tabular}{l|c|c|c|c|c|c}
\hline \multicolumn{1}{c|}{ Bahan Pakan } & $\begin{array}{c}\text { Protein } \\
(\%)\end{array}$ & $\begin{array}{c}\text { ME } \\
(\mathrm{Kkal} / \mathrm{kg})\end{array}$ & $\mathrm{Ca} \mathrm{( \% )}$ & $\mathrm{P} \mathrm{( \% )}$ & $\begin{array}{c}\text { Lemak } \\
(\%)\end{array}$ & $\begin{array}{c}\text { SK } \\
(\%)\end{array}$ \\
\hline Jagung kuning a $^{\text {a }}$ & 8,55 & 3105,66 & 0,37 & 0,44 & 2,97 & 2,42 \\
\hline Dedak $^{\mathrm{a}}$ & 10,45 & 1856,49 & 0,29 & 0,92 & 9,78 & 19,34 \\
Konsentrat Komersial $^{\mathrm{b}}$ & 34,00 & 3500,00 & 12,00 & 1,60 & 5,00 & 7,00 \\
\hline TDP $^{\mathrm{c}}$ & 20,88 & 2184,00 & 0,99 & 0,47 & 2,16 & 12,57 \\
Top Mix $^{\mathrm{d}}$ & 0,00 & 0,00 & 0,00 & 0,00 & 0,00 & 0,00 \\
\hline Mineral $^{\mathrm{e}}$ & 0,00 & 0,00 & 32,00 & 10,00 & 0,00 & 0,00 \\
\hline
\end{tabular}

Keterangan :

$\begin{array}{ll}\text { a } & \text { : Hartadi dkk. (2005) } \\ \text { b } & \text { : Label Konsentrat Komersial } \\ \text { c } & \text { : Hasil analisis Laboratorium Nutrisi Ternak Ruminansia dan Kimia } \\ & \text { Makanan Ternak Fakultas Peternakan Universitas Padjajaran (2007) } \\ \text { d } & \text { : Label Top Mix } \\ \text { e } & \text { : Label Mineral } \\ \text { TDP } & \text { : Tepung Daun Pepaya }\end{array}$

Berdasarkan bahan penyusun ransum yang digunakan di atas, maka diformulasikan sesuai dengan kebutuhan dalam penyusunan ransum perlakuan.
Susunan ransum penelitian dan kandungan nutrisi selengkapnya disajikan pada Tabel 2.

Tabel 2. Susunan ransum penelitian dan kandungan nutrisi

\begin{tabular}{l|c|c|c|c}
\hline \multirow{2}{*}{\multicolumn{1}{c}{ Bahan Pakan }} & \multicolumn{4}{c}{ Ransum Perlakuan } \\
\cline { 2 - 5 } & R0 & R1 & R2 & R3 \\
\hline Jagung giling (\%) & 34 & 34 & 34 & 34 \\
\hline Dedak halus (\%) & 20,5 & 18,5 & 17,5 & 15,5 \\
\hline Konsentrat Komersial (\%) & 44 & 44 & 43 & 43 \\
\hline TDP* (\%) & 0 & 2 & 4 & 6 \\
\hline Top Mix (\%) & 0,5 & 0,5 & 0,5 & 0,5 \\
\hline Mineral (\%) & 1 & 1 & 1 & 1 \\
\hline Total (\%) & 100 & 100 & 100 & 100 \\
\hline Kandungan Nutrien : & & & & \\
\hline Protein kasar (\%) & 20,01 & 20,22 & 20,19 & 20,40 \\
\hline ME (kkal/kg) & 2976,50 & 2983,06 & 2973,17 & 2979,72 \\
\hline Serat kasar (\%) & 7,87 & 7,73 & 7,72 & 7,58 \\
\hline Ca (\%) & 5,76 & 5,77 & 5,67 & 5,68 \\
\hline P (\%) & 1,04 & 1,03 & 1,02 & 1,01 \\
\hline Lemak kasar (\%) & 5,21 & 5,06 & 4,96 & 4,81 \\
\hline Tyynyyy
\end{tabular}

* Tepung Daun Pepaya

Rancangan yang digunakan adalah rancangan acak lengkap (RAL). Percobaan ini menggunakan puyuh petelur fase produksi berumur 36 minggu sebanyak 80 ekor yang dibagi dalam 4 perlakuan, yaitu: 
$\mathrm{R} 0=$ Ransum control (tidak mengandung Tepung Daun Pepaya)

$\mathrm{R} 1=$ Ransum mengandung 2\% Tepung Daun Pepaya

$\mathrm{R} 2$ = Ransum mengandung 4\% Tepung Daun Pepaya

R3 = Ransum mengandung 6\% Tepung Daun Pepaya

Puyuh petelur tersebut terbagi dalam 4 perlakuan dengan 5 ulangan, dalam setiap ulangan berisi 4 ekor puyuh yang ditempatkan secara acak pada kandang baterai. Ransum dan air minum diberikan ad libitum. Variabel yang diamati antara lain konsumsi ransum (g/ekor/hari), produksi telur (butir/ekor/minggu), berat telur (g/butir), dan konversi ransum. Data yang diperoleh ditabulasikan dan dianalisis dengan ANOVA dan jika menunjukkan berbeda nyata maka diuji dengan Duncan's Multiple Range Test (DMRT).

\section{HASIL DAN PEMBAHASAN}

Pemberian tepung daun pepaya (TDP) dalam ransum sampai taraf $6 \%$ berpengaruh sangat nyata $(\mathrm{P}<0,01)$ terhadap konsumsi dan konversi ransum tetapi tidak berpengaruh nyata $(\mathrm{P}>0,05)$ terhadap produksi telur dan berat telur. Hasil pengamatan selama penelitian disajikan pada Tabel 3 .

Tabel 3. Rataan konsumsi ransum, produksi telur, berat telur dan konversi ransum

\begin{tabular}{|c|c|c|c|c|}
\hline \multirow[b]{2}{*}{ Perlakuan } & \multicolumn{4}{|c|}{ Variabel yang diamati } \\
\hline & $\begin{array}{c}\text { Konsumsi Ransum } \\
\text { (gram/ekor/hari) }\end{array}$ & $\begin{array}{c}\text { Produksi Telur } \\
\text { (butir/ekor/minggu) }\end{array}$ & $\begin{array}{l}\text { Berat Telur } \\
\text { (gram/butir) }\end{array}$ & Konversi Ransum \\
\hline R0 & $30,49 \pm 0,40^{\mathrm{a}}$ & $5,13 \pm 0,31$ & $10,66 \pm 0,13$ & $2,86 \pm 0,05^{a}$ \\
\hline R1 & $29,83 \pm 0,15^{b}$ & $5,26 \pm 0,23$ & $10,77 \pm 0,14$ & $2,77 \pm 0,04^{a}$ \\
\hline R2 & $30,92 \pm 0,34^{\mathrm{a}}$ & $5,36 \pm 0,23$ & $10,89 \pm 0,18$ & $2,85 \pm 0,03^{\mathrm{a}}$ \\
\hline R3 & $27,75 \pm 0,71^{\mathrm{c}}$ & $5,01 \pm 0,07$ & $10,68 \pm 0,12$ & $2,61 \pm 0,09^{b}$ \\
\hline Keterangan & $* * *$ & ns & ns & $* * *$ \\
\hline Keterangan & $\begin{array}{ll}* * * & =\text { Menunjukk } \\
\text { ns } & =\text { Menunjukk } \\
\text { R0 } & =\text { Ransum ko } \\
\text { R1 } & =\text { Ransum me } \\
\text { R2 } & =\text { Ransum me } \\
\text { R3 } & =\text { Ransum me }\end{array}$ & $\begin{array}{l}\text { berpengaruh sangat } \\
\text { n berpengaruh tidak } \\
\text { trol (tanpa tepung da } \\
\text { gandung } 2 \% \text { tepung } \\
\text { gandung } 4 \% \text { tepung } \\
\text { gandung } 6 \% \text { tepung }\end{array}$ & $\begin{array}{l}\text { yata }(\mathrm{P}<0,01) \\
\text { yata }(\mathrm{P}>0,05) \\
\text { n pepaya) } \\
\text { aun pepaya } \\
\text { aun pepaya } \\
\text { aun pepaya }\end{array}$ & \\
\hline
\end{tabular}

\section{Konsumsi Ransum}

Rataan konsumsi ransum puyuh selama penelitian pada masing-masing perlakuan berkisar antara 27,75-30,92 gram/ekor/hari. Hasil analisis ragam menunjukkan bahwa pemberian tepung daun pepaya sampai taraf $6 \%$ berpengaruh sangat nyata $(\mathrm{P}<0,01)$ terhadap konsumsi ransum puyuh. Konsumsi ransum puyuh yang mendapat 
perlakuan tepung daun pepaya $4 \%$ mampu meningkatkan konsumsi ransum tetapi pada taraf $6 \%$ tepung daun pepaya dalam ransum cenderung lebih rendah daripada yang mendapat perlakuan daun pepaya $2 \%$ dan kontrol (tanpa daun pepaya).

Rataan konsumsi ransum kontrol (R0) berbeda dengan perlakuan R1 dan R3, namun pada perlakuan R0 tidak berbeda nyata dengan perlakuan R2. Hal ini diduga karena penggunaan daun pepaya yang memiliki rasa pahit dari senyawa alkaloid carpain sehingga menyebabkan perubahan palatabilitas ransum. Perubahan palatabilitas ransum pada puyuh ini disebabkan juga karena lidah unggas yang memiliki sistem perasa berupa gustative atau taste buds yang berguna untuk mengenali rasa makanannya meskipun jumlah titik perasa pada unggas lebih sedikit apabila dibandingkan dengan jumlah titik perasa hewan lainnya, namun sensitivitas unggas terhadap rasa lebih tinggi (Amrullah, 2004). Konsumsi ransum dapat dipengaruhi oleh beberapa faktor, salah satunya yaitu palatabilitas (Anggorodi, 1995).

Penelitian yang telah dilakukan tentang penggunaan tepung daun pepaya pada ransum komersial sampai taraf $6 \%$ pada ayam petelur jantan memberikan pengaruh negatif terhadap konsumsi ransum (Bota, 2007). Hasil penelitian Soares et al. (2003) menunjukkan bahwa pemberian level protein 16-24\% dalam pakan puyuh tidak berpengaruh nyata $(\mathrm{P}>0,05)$ terhadap konsumsi ransum.

\section{Produksi Telur}

Rataan produksi telur puyuh selama penelitian pada masing-masing perlakuan berkisar antara 5,01-5,36 butir/ekor/minggu. Hasil analisis ragam menunjukkan bahwa pemberian tepung daun pepaya dalam ransum memberikan pengaruh tidak nyata $(\mathrm{P}>0,05)$ terhadap produksi telur puyuh. Dapat dilihat pada Tabel 5. bahwa rataan produksi telur puyuh dengan perlakuan ransum yang mengandung 6\% tepung daun pepaya mengakibatkan produksi telurnya cenderung lebih rendah bila dibandingkan produksi telur dengan perlakuan tepung daun pepaya $2 \%, 4 \%$ dan perlakuan kontrol.

Beberapa faktor yang sangat mempengaruhi produksi telur yaitu faktor lingkungan, genetik, dan kandungan protein dalam ransum (Scott et al., 1982; Ensminger et al., 1990). Selain dapat meningkatkan efisiensi pencernaan, daun pepaya juga memiliki faktor pembatas yang merupakan zat antinutrisi (tanin) yang dapat mempengaruhi fungsi asam amino dan kegunaan dari protein. Penurunan 
produksi telur dengan pemberian tepung daun pepaya dalam ransum hingga taraf 6\% diduga karena tingginya kandungan tanin sebesar 5-6\%. Oleh karena itu perlu penanganan yang khusus dalam penggunaan daun pepaya, yaitu dengan mengeringkannya kemudian diolah menjadi tepung dengan harapan dapat menurunkan atau bahkan menghilangkan pengaruh anti nutrisi tersebut.

Penelitian sebelumnya yang dilaporkan Widjastuti (2009) terhadap ayam Sentul umur 36 minggu dengan pemberian tepung daun pepaya sampai batas $10 \%$ tidak berpengaruh negatif terhadap produksi telur, sejalan dengan penelitian Sutama (2008) juga menemukan bahwa penambahan tepung daun pepaya sampai taraf $3 \%$ tidak berpengaruh nyata terhadap produksi telur ayam Hysex Brown umur 19 minggu.

\section{Berat Telur Puyuh}

Rataan berat telur puyuh selama penelitian pada masing-masing perlakuan berkisar antara 10,66-10,89 gram/butir. Hasil analisis ragam menunjukkan bahwa pemberian tepung daun pepaya dalam ransum puyuh taraf $2 \%, 4 \%$ dan $6 \%$ berpengaruh tidak nyata $(\mathrm{P}>0,05)$ terhadap rataan berat telur puyuh yang dihasilkan. Nilai rataan berat telur menunjukkan bahwa berat telur R0 cenderung rendah dibandingkan rataan berat telur yang diberi perlakuan ransum mengandung tepung daun pepaya (TDP). Nilai rataan telur R1 $(10,77$ gram/ekor/hari), $\quad$ R2 $\quad(10,89$ gram/ekor/hari), $\quad$ R3 $\quad(10,68$ gram/ekor/hari) lebih tinggi dibandingkan R0 (10,66 gram/ekor/hari). Lebih tingginya rataan berat telur puyuh yang diberi ransum dengan kandungan $4 \%$ tepung daun pepaya diduga karena kandungan nutrisi dalam daun pepaya memiliki banyak vitamin A dan $\beta$ karoten yang tidak mampu meningkatkan katabolisme lemak (Sutama, 2008) dan sintesis protein pada putih dan kuning telur sehingga menghasilkan berat telur yang sama (Schunack et al., 1990).

Penelitian sebelumnya telah dilaporkan Sutama (2008) pemberian tepung daun pepaya sampai taraf $3 \%$ pada ayam petelur Hysex Brown tidak memberikan pengaruh nyata terhadap berat telur ayam. Selanjutnya Widjastuti (2009) juga melaporkan bahwa pemberian tepung daun pepaya sampai taraf $10 \%$ juga tidak berpengaruh nyata terhadap berat telur ayam Sentul.

\section{Konversi Ransum}

Rataan konversi ransum selama penelitian pada masing-masing perlakuan berkisar antara 2,61-2,86. Hasil analisis ragam menunjukkan bahwa pemberian tepung daun pepaya dalam ransum puyuh 
memberikan pengaruh yang sangat nyata $(\mathrm{P}<0,01)$ terhadap konversi ransum. Hal ini menunjukkan pemberian tepung daun pepaya sampai taraf $6 \%$ dapat mempengaruhi efisiensi penggunaan ransum.

Nilai rataan konversi ransum $\mathrm{R} 0$ sebagai perlakuan kontrol cenderung tinggi bila dibandingkan dengan yang diberi tepung daun pepaya yaitu R1 $(2,77)$, R2 $(2,85)$ dan R3 (2,61). Hal ini mengindikasikan bahwa efisiensi ransum R3 lebih baik bila dibandingkan dengan perlakuan lainnya. Sementara itu, perlakuan kontrol memiliki rataan konversi ransum yang tinggi sehingga dapat disimpulkan bahwa pemberian tepung daun pepaya sampai taraf $6 \%$ dapat mempengaruhi efisiensi penggunaan ransum.

Hasil penelitian ini tidak sejalan dengan beberapa pendapat. Penelitian sebelumnya telah dilaporkan Sudjatinah et al. (2005) bahwa pemberian ektrak daun pepaya pada ayam broiler tidak memberikan pengaruh nyata $(\mathrm{P}>0,05)$ terhadap konversi ransum. Selanjutnya pemberian level protein yang berbeda dalam ransum puyuh memberikan pengaruh tidak nyata $(\mathrm{P}>0,05)$ terhadap konversi ransum puyuh (Soares et al., 2003). Sejalan dengan penelitian Zahra et al. (2012) pemberian ransum bebas pilih juga tidak memberikan pengaruh nyata $\quad(\mathrm{P}>0,05) \quad$ terhadap konversi ransum. Hal tersebut diduga karena adanya pengaruh terhadap konsumsi ransum namun tidak adanya pengaruh perlakuan terhadap bobot telur yang mempengaruhi konversi ransum.

\section{KESIMPULAN}

Berdasarkan hasil penelitian ini dapat disimpulkan bahwa pemberian tepung daun pepaya dalam ransum puyuh petelur pada taraf $4 \%$ dapat meningkatkan konsumsi ransum, berat telur, produksi telur dan konversi ransum, tetapi pada taraf $6 \%$ dapat menurunkan konsumsi dan konversi ransum tanpa menurunkan produksi telur dan berat telur puyuh.

\section{DAFTAR PUSTAKA}

Amrullah, I.K. 2004. Nutrisi Ayam Broiler.Ed ke-2. Lembaga Satu Gunung Budi, Bogor.

Anggorodi, H. R. 1995. Ilmu Makanan Ternak Umum. PT. Gramedia Pustaka Utama, Jakarta.

Anonimous. 1981. Daftar Komposisi Bahan Makanan. Departemen Kesehatan Republik Indonesia. Bhratara Karya Aksara, Jakarta.

Ardina, Y. 2007. Development of Antiacne Gel Formulation and Minimum Inhibitory Concentration 
Determination from Carica Papaya Leaves Extract (Carica papaya A Linn.).

http://digilib.itb.ac.id/gdl.php.

diakses 22 Oktober 2013.

Bota, B. J. 2007. Pengaruh Penambahan Tepung Daun Pepaya (Carica papaya L.) dalam Pakan Komersil terhadap Konsumsi Pakan, Pertambahan Bobot Badan dan Konversi Pakan pada Ayam Pedaging Jantan. Undergraduate Tesis Airlangga University Library. Surabaya.

Hartadi, H., S. Reksohadiprodjo, dan A. D. Tillman. 2005. Tabel Komposisi Pakan untuk Indonesia. Cetakan Ke Lima. Gadjah Mada University Press, Yogyakarta.

Kamaruddin, M. dan Salim. 2003. Pengaruh Pemberian Air Perasan Daun Pepaya Pada Ayam : Respon Patofisilogik Hepar. Jurnal Sain Veterinet 20 (1) : $37-43$.

Laboratorium Nutrisi Ternak Ruminansia dan Kimia Makanan Ternak Fakultas Peternakan Universitas Padjajaran. 2007. Fakultas Peternakan Universitas Padjajaran, Bandung.

Machasin. 2007. Pengaruh Penambahan Tepung Daun Pepaya (Carica papaya L.) dalam Ransum terhadap Status dan Kadar Asam Urat Darah Ayam Buras Super. Skripsi Fakultas Pertanian Universitas Diponegoro Semarang, Semarang.

Paramita. W., H. Setyono, T. Nurhayati dan M. Lamid. 2003. Prospek Pemanfaatan Daun Pepaya untuk Meningkatkan Produksi Telur dan Konsumsi Pakan pada Ayam Buras. J. Penelitian Medika Eksata (2) : 10 $-16$.

Scott, M.L., MC. Nesheim, and R.J. Young. 1982. Nutrition of the Chicken. $3^{\text {rd }}$ ed. Published by ML Scott and Associates, Ithaca, New York.

Soares R da T.R.N., J.B. Fonseca, S.A.S. de $\mathrm{O}$ dos, and M.B. Mercandante. 2003. Protein Requirement of Japanese Quail (Coturnix coturnix japonica) During Rearing and Laying Periods. Revista Brasileira de Ciencia Avicola 5 (2) : 153-156.

Sudjatinah, C.H. Wibowo, dan P. Widiyaningrum. 2005. Pengaruh Pemberian Ekstrak Daun Pepaya terhadap Tampilan Produksi Ayam Broiler. Jurnal Animal Agricultural 30 224-228. 
Sutama, I. N. S. 2008. Daun Pepaya dalam Ransum Menurunkan Kolesterol pada Serum dan Telur Ayam. Jurnal Veteriner 9 (3) : 152-156.

Steel, R.G.D., dan J.H. Torrie. 1993. PrinsipdanProsedurStatistikaSuatuPe ndekatanBiometrik. Terjemahan: $\mathrm{M}$. Syah. PT. GramediaPustakaUtama, Jakarta.

Widjastuti, T. 2009. Pemanfaatan Tepung Daun Pepaya (Carica papaya L.) dalam Upaya PeningkatanProduksi Dan Kualitas Telur Ayam Sentul. Jurnal Agroland 16 (3) : 268-273.

Zahra, A.A., D. Sunarti, dan E. Suprijatna. 2012. Pengaruh Pemberian Pakan Bebas Pilih (Free choice feeding) terhadap Performans Produksi Telur Burung Puyuh (Coturnix coturnix japonica). Jurnal Animal Agricultural 1 (1) : 1 - 11. 